\title{
DEPARTMENT OF HEALTH
}

OF THE

\section{CITY OF NEW YORK}

No. 26

REPRINT SERIES

JANUARY, 1916

\section{HEALTH ASPECTS OF SCHOOL LUNCHES}

BY

EDWARD F.: BROWN

Executive Secretary, New York School Lunch Committee, Association for Improving the Condition of the Poor

(SECOND EDITION)

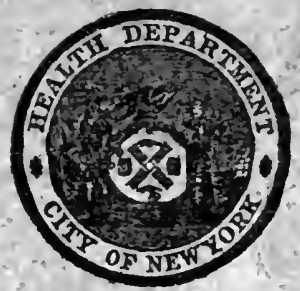

Public health is purchasable. Within natural limitations a community can determine its own death rate 


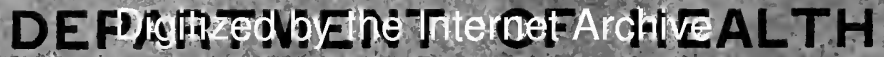 in 2007 with of funding from city of CoreorationoRK}




\title{
DEPARTMENT OF HEALTH \\ OF THE
}

\section{CITY OF NEW YORK}

\section{HEALTH ASPECTS OF SCHOOL LUNCHES}

\author{
BY \\ EDWARD F. BROWN \\ Exccutive Secretary. Ncw York School Lunch Committee, Association for Improving the \\ Condition of the Poor

$$
\text { (SECOND EDITION) }
$$

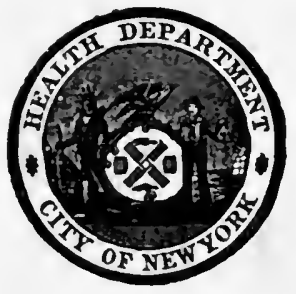

Public health is purchasable. Within natural limitations a community can determine its own death rate 


\title{
Health Aspects of School Lunches.
}

\author{
By \\ EDWARd F. BROWN, \\ Executive Secretary, New York School Lunch Committee, \\ Association for Improving the Condition of the Poor.
}

\section{Food and Health.}

There is a growing recognition on the part of the medical profession of the value of the prophylactic uses of food. Rosenau has indicated the importance of the relationship between diet and the prevention and treatment of tuberculosis, diabetes, nephritis; arteriosclerosis, gout, rheumatic affections, other disorders of metabolism, dyspepsia, gastric ulcer, infantile diarrhoea and many other disturbances. Unfortunately, the significance of the relationship is not apparent until the victim, stricken with disease, is compelled to restrict or alter his diet to adjust the body to its normal process. Given improper food, man ails, degenerates and eventually must succumb. Food education, therefore, especially to the young, is a social precaution which should result in more healthful living, lessen the incident of sickness and lengthen life.

The organized feeding of school children recognizes the possibilities of the school lunch as a factor in the public health propaganda. The health aspects of the school feeding movement are varied, and any discussion of it leads us to consider the larger problems of food and how it affects health. We give here a summary of how food may disastrously affect health, taking the admirable material collected by Rosenau:

1. Some foods may be directly poisonous ; an example of this is seen in plants which contain poisonous alkaloids.

2. There may be a development of poisons in foods as a result of bacterial contamination; an example of this is sausage poisoning.

3. Foods which are poisonous because of adulterations, such as, from the addition of lead, copper, arsenic, formaldehyde, sulphites, etc., to preserve appearance or color, or to alter taste.

4. Foods containing animal parasites such as trichina and tapeworms. These infections occur usually as antemortem infections in the animal. On plant life infection may be carried through the eggs or larvae of the animal parasites. 
5. Foods containing vegetable parasites. Pathogenic bacteria are not infrequently found in both animal and vegetable foods. They are more frequent, however, in animal foods.

6. Foods may also contain special poisons, such as ergot in rye or solanin in sprouted potatoes.

7. Food may be inimical to health where it is taken in large quantities or where certain foods are ingested without proper balance.

Excess feeding predisposes to fat, and not infrequently to arteriosclerosis and diseases of the liver and kidneys. On the other hand, an insufficient quantity may result in starvation.

An unvaried diet often leads to disease. This is particularly true of the polished rice eaters of India, who are known to develop beri-beri.

The absence of organic acids induces scurvy; impaired alimentation often results in rickets.

Foods which are highly spiced and stimulating irritate the digestive system and organs of excretion.

In cliildren, an excess of food produces a condition resembling acidosis.

An unbalanced ration, long continued, is apt to be harmful, such as was the case with an English physician who had nourished himself with sugar alone for a month, as a result of which he became weak and shortly thereafter died.

An excess of protein induces gastro-intestinal putrefactive changes, with danger of auto-intoxication.

Indigestion is the result, frequently, of eating when the body is fatigued or when mastication is impaired.

A dietetic error of great prevalence is the lack of sufficient quantities of drinking water.

There may also be danger in foods which are ingested by persons possessed of some idiosyncrasy.

Serious defects, and common ones, also, are high acidities and low mineral contents in diets.

\section{Early Training in Food Economy.}

During the plastic and responsive period of a child's life, the principles of correct feeding should be carefully taught. Dr. Edward Huntington Williams, in his work on "Increasing Your Mental Efficiency," says: "If the child, during its early years, has been given proper training, its own instincts will be its best guide in the selection of proper nourishment later in life."

The lesson is best taught in the actual, practical preparation of food in the school. The advantage of early training in school lies in the fact that school children are subjected to all the snares of ignorance and incontinence. The frauds perpetrated on them by unscrupulous vendors, who flash highly colored candies before their innocent eyes, are nothing short of premeditated poisoning.

The school lunch service, therefore, developed to its fullest capacity along educational and social lines- 
1. Provides food for children at school, preventing

(a) Hurried ingestion of food at home.

(b) Going to and from school in intemperate weather.

2. Guards the food supply of those children, who, unable to go home, are otherwise compelled to

(a) Buy food from pushcarts, etc.

(b) Bring a dry lunch from home.

3. Gives splendid opportunity to teach school children the science of feeding, including the purchase, preparation and hygiene of food.

\section{The Genesis of School Feeding.}

The medical profession is to be credited with initiating and developing the movement to feed children at school. Its beginning in England, for instance, can be traced to a memorandum issued by the Director General of the Army Medical Service which followed the wholesale rejections of recruits for military duty because of their physical disability. The national defense was endangered, and an inquiry was accordingly made into the causes. The Interdepartmental Committee on Physical Deterioration reported that the reasons for this condition, which required the lowering of the standards of fitness, were destitution, ignorance and parental indifference -all of which may be traced back to poverty. It is notable that these revelations came after a rapid rise of industrialism which followed the discovery and use of labor-saving machinery. This attracted much of the labor to the nills, created the system of child labor, overwork for women and the exploitation of men. The first fruit of this system was poverty, which in turn produced the things which caused the physical decadence of the yeomanry of old England. The children were being reared as weaklings, incapable of resisting disease and largely impervious to education. As a measure of relief for this deplorable situation, the inquisitorial council recommended a school lunch service where needy children could be fed at the ptublic expense.

Developing as a relief measure in England, calculated to heal a social disease in an advanced stage, it is not strange that, profiting by England's neglect, the American movement should have developed along the lines of feeding children before they became the objects of public charity. The difference between the two systems is that the English is a relief measure open to the necessitous and based on repairing damage already done, while the American is preventive in that it seeks to avoid the necessity for making such social repairs.

In America, characteristically democratic, the food is sold to all children, while the English system is restricted to children of poverty.

\section{Organized School Feeding in New York.}

In 1907 the New York public was aroused by the alarming statements which appeared in public print that thousands of children went to school each day suffering from lack of food. An investigation was made and, as a result of the popular interest, there was organized the New York School Lunch Committee, the purposes of which are: 
1. The provision of nourishing lunches on a self-supporting basis for all school children.

2. Special observation of children whose physical condition is such as to give evidence of lack of proper nourishment in order to determine the underlying causes by a study of their homes and environment. An extension of this aim requires that these selected cases be followed up to the end that the proper agency may be apprised and appropriate action taken.

3. The formation of special classes of mothers for instruction in the proper care of children, especially of cases of poor nourishment.

At the present writing, there are 20 schools, registering 32,000 children, where the penny-a-portion service hereinafter described is operated.

The need for such a community service was naturally most pressing in, the districts where people were poor; where mothers worked in the factory by day, and where the children depended for food on the few pennies which purchased candy from the vendors about schoolhouses.

An experiment was tried in the equipment of a kitchen in a school building, where soup, sandwiches, puddings and cocoa were provided at the rate of one cent a portion-the child being required to first purchase a bowl of hot soup.

Fundamentally, the service is devoid of any mark of poor relief. During the last school term 1,249,489 portions of food were sold, for which the children paid $\$ 12,494.89$. In supplying nearly a million and a half portions, a net deficit of $\$ 4,624.52$ was incurred. This is equal to a little over a third of a cent per portion, and was paid from funds entrusted to the Department of Social Welfare of the New York Association for Improving the Condition of the Poor by Mrs. Elizabeth Milbank Anderson.

\section{A Guarded Food Supply.}

Naturally, in any scheme for feeding large groups of children, where the prime object is the rearing of a vigorous race, a scientific basis is essential. The working force of the Committee is headed by a dictitian who is responsible for the character of the food and service. The principles on which food is selected are: (1) nourishment, (2) palatability, (3) purity, (4) seasonability, (5) inoffensiveness to racial or religious preferences, (6) similarity to home food, (7) diet balanced according to food principles.

When the Committee is assured that the food meets these requirements, a sample order of the raw product is secured.

\section{Standardization of Foods.}

The sample is then submitted to three tests: (1) chemical, (2) bacteriological, (3) food value.

The standards set provide that the food sliall be chemically free from harmful ingredients and contain no bacteria likely to 
result in injury. It is not enough that food be negatively edibleit must meet the positive test of food value. Somewhere in the day's menu there must be provided protein to supply the need for nitrogen ; carbohydrates and fat to generate heat and energy; salts, vegetables, acids and water supply to mineral matter and solvents for metabolism.

Co-operation with the New York City Health Department has brought about the most encouraging results. Analyses have been made by the Department and by the laboratories connected with the universities. Moreover, health authorities out of town have always aided when asked to inspect the manufactories in their communities.

\section{The Hygiene of Food Manufacture.}

When there is every sign that the product itself is pure, the place where the food is manufactured is inspected to ascertain under what conditions the food is made.

Preference in purchasing is given to firms where the-

1. Bases of the food product are pure.

2. Handling is clean.

3. Manufacturing establishment is hygienic.

4. Employees are examined to detect their possibilities of transmitting disease.

5. Standards of hours and wages are high.

The social value of encouraging trade where decent conditions of work and welfare prevail is not only a just recognition of good public service, but a rebuke to the unsocial manufacturer who thrives on adulterations, overwork and underpay. It is easy to recognize here another measure in the interest of public health, for in the degree that we demand and secure livable conditions of labor will we secure a diminution of sickness, incapacity and death.

\section{The Public Service Rendered by the Cautious Food Purchase.}

Where foods are found to contain harmful matter, or where the conditions of manufacture or sale are unhygienic, information is laid before the health authorities for action. This usually prevents the further distribution of a product which is likely to cause injury. In addition, the firm is notified that its product or the handling of the same has been found to be such that the product is considered unsafe for feeding to children, and that the Committee cannot engage in trade with it.

There is an educational advantage in this system which cannot be overestimated. Certainly many manufacturers are made, in this way, to realize that they are losing trade, and this tends to make them pay more attention to decent handling of food products. Sometimes the cause of complaint is merely a little carelessness in handling at the factory or a slight infraction of the law. In such cases the Health Department communicates the fact to us and also to the manufacturer. This results in a clearing up of the cause of the complaint, as is evidenced by the subjoined sample correspond- 
ence, which is typical. From the Committee to the Commissioner of Health :

"This Committee has been asked to purchase candies for the penny lunch service in the places mentioned below. Before we do so, I should like to ask whether it would be possible for you to assign a food inspector to visit these places and let us know whether, in his judgment, the premises and products are of such a character that we may feel safe in purchasing supplies there for the children of the schools."

\section{From the Commissioner of Health to the Committee:}

"In further answer to your recent communication asking the co-operation of this Department in making an inspection of certain candy manufactories from which it has been recommended that you purchase candies for sale in the 'penny lunch service,' the Commissioner directs me to inform you that the reports of our chemical laboratory show in each instance that poisonous metals are not found to be present and the candies are therefore considered fit for human consumption.

"Inspections have been made by our Bureau of Food and Drugs with the purpose of securing sanitary conditions in the factories of the concerns named in your communication. The factories of the *** companies were found in good sanitary condition, warranting no further action by this Department. The factories of the $* * *$ companies were found not entirely satisfactory, and notices were issued by this Department requiring a correction of the insanitary conditions found. Reinspections disclosed that the work of placing these establishments in conformity with our orders is in progress, and it is expected that they will meet our requirements within a few days."

\section{Publicity and Purity of Foods.}

An additional precaution taken by the Committee to ensure the purity of the food sold in its school lunch service consists in carefully scanning the lists of convicted food adulterers prepared weekly by the Health Department. Should any of our traders' names appear in the blacklist business dealings with them would be immediately discontinued.

\section{Hygiene of Equipment.}

It is of the utmost importance to secure sanitary and "filth proof" kitchen and serving equipment. Unfortunately, many eating utensils are constructed along aesthetic rather than sanitary lines. Cups, bowls, saucers, spoons, knives, forks, boilers, etc., often contain raised lines about the base or handles which serve no utilitarian purpose, but are placed there for ornamentation. These are admirable recesses for the accumulation of food particles or other material which sometimes the most careful washing does not reach. The planning of equipment, construction, storage and handling offers splendid opportunities for anyone interested in protection against 
food contamination. All this naturally inures to the benefit of the children in at least two distinct ways:

1. It removes the possibility of food contamination.

2. By suggestion and association the children are taught to observe hygienic precautions.

The movement, unfortunately, has not as yet progressed sufficiently to have the kitchen used as an object lesson to the children. These little lessons might well be taught as a part of the child's school education.

\section{Medical Examination of Employees.}

In order to prevent any possibility of disease transmission in the preparation and handling of food, the Committee asked the Health Department to make a thorough medical examination of the school lunch employees to ascertain whether they were free from disease and were not disease carriers. Each employee submitted to a complete physical examination (body naked), and the examination included throat cultures (diphtheria bacilli) and blood tests made for typhoid. As an added precaution, facilities for free vaccination against smallpox were offered to each employee who had not been vaccinated within the past three years, as a result of which two-thirds of the employees were thus immunized.

In addition, 100 children who assist in the lunch service also submitted to a special examination by medical inspectors. We received permission from the Department of Health and the Department of Education authorizing the medical inspectors to make these examinations while the children were stripped to waistline. In the case of girls, nurses were present at the examination, and the examination itself was made by women physicians.

In all, 131 persons were examined, of whom 31 were employees and 100 student helpers. A striking fact is the almost even percentage of defects found in the two classes of help, employees and pupils, though, on the whole, the records of the employees make the better health showing. The two most serious ailments, pulmonary tuberculosis and syphilis, were disclosed in pupils, therc being two suspicious cases and one positive of the first, and two suspicious cases of the latter. Of the throat cultures, one in an employee showed diphtheria bacilli. Two trachoma cases were found among the pupils.

Pediculosis capitis, so common in the school population, was found in 10 per cent. of either group.

Of the Widal tests, two showed positive in employees and one in a pupil. The figures were the same for acute bronchitis; chronic: bronchitis was found in one employee, ringworm in one pupil.

The result demonstrates very clearly that the exaninations were worth while, inasmuch as they disclosed, even though in a very small percentage of cases, a situation which needed attention. Naturally the recommendations made by the medical inspectors as to the disposition of those employees whom it was found unwise to continue were immediately followed, and in the case of school children, nurses have visited the homes and had the children treated for their condition. 
The 1914-1915 examinations were made by the physicians of the Department of Education.

\section{Scientific Feeding.}

The strict observance of dietetic principles is a real justification of the school lunch service. It is common knowledge that the improper selection of food for children is likely to leave their bodies undeveloped or an organic process impaired.

For this reason it is of the utmost importance that the food served the children be selected and prepared on a wholly scientific basis. The principle on which school feeding is founded is that it implies something needful to the child which the home for some reason has failed to meet. Chief among its services is the scientific nature of its diet. It is undoubtedly true that many housewives, particularly among the poorer classes (where there has been little opportunity to learn) are unfamiliar with the fundamental principles of feeding and the function and use of food.

In many households foods are prepared, among other reasons, because they (1) require little labor; (2) satisfy a peculiar taste; (3) are apparently clieap. These considerations do not cover the balance of necessary ingredients, seasonability, abundance or variety. Such haphazard feeding sooner or later culminates in illness, and it is often a source of wonder to many parents why their offspring should suffer since they were fed. It is no answer to such a condition that children should be fed at school. The wiser course would be to teach mothers, and the girls who are to be the mothers of to-morrow, how and what to feed children. Since we are overrun with housewives who neither have the time nor the inclination to learn how and what to cook, we must guard their children against a similar lack of knowledge. This the school lunch does admirably for those children with whom it comes in contact. Here the foods are chosen to build up the worn-out tissues and yield the energy to cnable the child to grow and learn.

During the past year the Committee, in co-operation with Dr. Frank C. Gebhart of Cornell University, subjected all the foods served by the Committee to laboratory tests. This was done in order to measure the caloric value of the foods, in order that some standardization might be effected. Thus it is planned to give to a child between 400 and 500 calories for three cents. With properlv chosen food, the child may secure an adequate measure of nourishment for an expenditure of three cents. The following table will show the caloric value of the foods on the Committee's dietary:

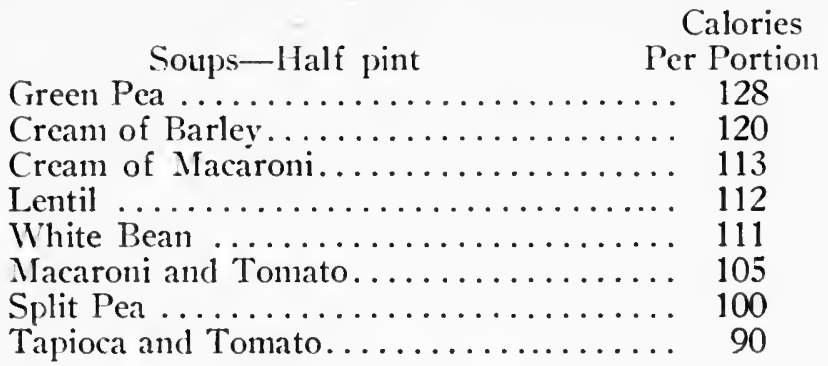


Corn ......................... 90

American Vegetable ................ 85

Scotch Broth ................. 84

Clam Chowder .................. 82

Foods Other than Soups

Baked Beans .................... 167

Baked Macaroni .................. 89

Beet Salad ....................... 57

Potato Salad ...................... 117

Lentil Salad ...................... 189

Vegetable Salad ................. 76

Butter Sandwich ................. 247

Egg Sandwich ................. 236

Jam Sandwich ................. 227

Prune Sandwich ................... 243

Cheese Sandwich .................. 250

Pot Cheese Sandwich.............. 212

Apple Jelly Sandwich............. 240

Apple Sauce ...................... 108

Rice Pudding ................. 108

Bread Pudding ................... 131

Chocolate Pudding ............... 101

Spice Cakes ................. 108

Vanilla Cakes ................. 28

Jelly Tarts ................... 83

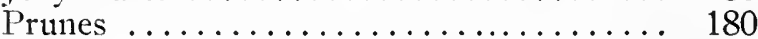

Dates ..................... 200

Average $\ldots \ldots \ldots \ldots \ldots \ldots \ldots . \ldots \ldots$

The calorie aggregate of some of the typical trays of food purchased, none of which totaled a cost of more than three cents, are shown here:

Green Pea Soup....... 128 Vegetable Soup ....... 85

Bread, Two Slices...... 200 Egg Sandwich ........ 236

Apple Sauce ......... 108 Rice Pudding ......... 108

$\overline{436} \quad \overline{429}$

Cream of Barley..... ... 120 Clam Chowder ........ 82

Cheese Sandwich ....... 250 Butter Sandwich ....... 247

Chocolate Pudding ..... 101 Jelly Tart .......... 83

472413

Macaroni and Tomato.... 105 Bean Soup ........... 111

Apple Jelly Sandwich.... 240 Bread, Two Slices....... 200

Cocoa ............. 100 Prunes ............. 180

445491 


\section{Food Waste and Food Education.}

Many modern food customs conduce to waste. This presses hardest upon the poor because they can least afford it. To get the maximum good from food requires the most discriminating selection. This process is variously performed because it depends on individual initiative and requires constant attention. If we could have each family so manage its dietary as to get the maximum energy for the minimum cost, much of the widely exploited high cost of living would disappear.

Food consumers should prefer those foods whose manufacture, advertising and sale is conducted honestly. Murlin has pointed out that if each manufacturer were compelled to state, for instance, that "This can contains.... calories, of which....per cent. are proteins of Grade C," the difficulty would be overcome. Of course, we must do something more than merely state food values on cartons and cans. We must educate the masses as to the meanings of these phrases which to most are like the dead languages. These can, however, be brought home, even to the masses, as Dr. Lusk has pointed out, through rational educational work.

\section{Household Standards for Food.}

In the average household, food selection is a matter of tradition, routine and unconcern; food preparation a matter of family custom, unscientific knowledge, haste; food hygiene a lost, or, an unacquired art. Food consumption is wasteful; food knowledge is meagre, unscientific.

\section{Economics and Health.}

It has often been pointed out that health is in direct ratio to the economic condition of the population. Trained health officers, therefore, do not fail to insist that industrial readjustments are the foundation of a healthier state. To mention but a single example, we may cite the admirable report on infant mortality issued by Miss Lathrop, which shows that the mortality of infants is in inverse ratio to wages. So in food problems, it is necessary to teach the ultinate consumer what foods are, how they may be used to the greatest advantage, and how the wisest purchases may be made. This is a real health activity. Organized school feeding, through a rational educational scheme, offers fruitful possibilities along just thesc lines.

\section{Individual Diets.}

The school feeding movement has not progressed far enough to have permitted very wide experiments in the individualization of diets, such as those for the under-nourished, the anaemic, the crippled, etc. Owing, however, to the cosmopolitan character of the city schools, the Committee has had to divide the dietary into three general groups, namely, the Italian, the Jewish and the American. corresponding to the three large groups of children within our 
city schools. For the Italian children, those foods which are usually to be found in Italian homes have been provided. For the Jewish children, it has been necessary to provide "kosher" food, inspected by a rabbi and complying with the restrictions of the Talmudic code. The American children have been served with dishes which are characteristically American.

At the present time there are ten schools in which the kindergarten children and those of the classes for anaemic, ungraded and crippled children are supplied with milk and crackers in the middle of the morning. It has been the aim of the Committee to extend its lunch service to as many of the classes for cripples as possible. Moreover, special efforts have been made to reach the tuberculosis cripples, and for these a special diet has been arranged.

\section{The Uncontrolled Food Vendor.}

The school lunch service supplies the need for food where the home has failed to make such provision. The mothers who work out by day frequently make a practice of giving the child a few pennies to spend for lunch, but, which, as a matter of fact, the child usually spends for candies, fruits and other tid-bits. The push cart and basket venders of candies, cakes, fruits and similar foods have from time immemorial infested school neighborhoods, selling wares which have been exposed to filth and dirt, and often dangerously adulterated. On the East Side, it was not uncommon to find cakes which had been baked in tenement homes, sold from baskets without covers, and carrying dirt and filth to the children. Baskets of candies, cakes and fruits often remain in the homes of the vendors over night without proper protection against dust, dirt, flies, roaches, filth and other contamination.

\section{The Menace of Malnutrition.}

An examination of one-third of the school population in New York City by the medical inspectors of the Health Department in 1913 disclosed 13,999 cases of malnutrition. On the assumption that the same ratio of this defect is to be found in the unexamined two-thirds, there would be approximately 40,000 children in our schools whose health is impaired owing to a malnourished system. Curiosity has led the author to inquire into the subject of malnutrition in other cities. Information was sought from 41 of the largest American cities, but the reports were meagre and unsatisfactory. Only 15 of the cities reported the number of children examined and the number found malnourished. The information thus obtained is as follows:

$\begin{array}{lrc} & \begin{array}{c}\text { Children } \\ \text { Examined }\end{array} & \begin{array}{c}\text { Children } \\ \text { Malnourished }\end{array} \\ \text { Cincinnati, Ohio......... } & 36,438 & 1,619 \\ \text { Chelsea, Mass......... } & 2,766 & 98 \\ \text { Haverhill, Mass........ } & 7,976 & 152 \\ \text { New York, N. Y....... } & 330,179 & 13,999 \\ \text { Providence, R. I........ } & 3,021 & 359 \\ \text { Rochester, N. Y........ } & 18,497 & 945\end{array}$




\begin{tabular}{|c|c|c|}
\hline & $\begin{array}{l}\text { Children } \\
\text { Examined }\end{array}$ & $\begin{array}{l}\text { Children } \\
\text { Malnourished }\end{array}$ \\
\hline San Francisco, Cal. ...... & $\quad 5,576$ & 282 \\
\hline Worcester, Mass......... & 18,342 & 389 \\
\hline Springfield, Mass....... & 8,938 & 35 \\
\hline Albany, N. Y.......... & 2,861 & 139 \\
\hline Cleveland, Ohio......... & 61,578 & 671 \\
\hline Harrisburg, Pa. . . . . . . & 8,667 & 199 \\
\hline Louisville, Ky... . . . . . . & 13,190 & 59 \\
\hline Newark, N. J.......... & 27,971 & 940 \\
\hline Raleigh, N. C.......... & . $\quad 1,909$ & 133 \\
\hline Total-15 Cities.... & 547,909 & 29,019 or $5.3 \%$ \\
\hline \multicolumn{3}{|c|}{ XIX. Indications of Malnutrition. } \\
\hline \multicolumn{3}{|c|}{$\begin{array}{l}\text { cording to the chief medical inspector of England, the indi- } \\
\text { of malnutrition are to be found in (1) the relation between } \\
\text { and weight; }(2) \text { relation between height, weight and age; } \\
\text { eral appearance; (4) skin and subcutaneous tissue conditions; } \\
\text { scle tone and development; }(6) \text { state of mucous membrane; } \\
\text { or or listlessness which may appear in child's facial expres- } \\
3) \text { carriage; }(9) \text { movements; (10) voice; (11) interest; (12) } \\
\text { n; (13) appetite. }\end{array}$} \\
\hline
\end{tabular}

\section{Cause of Malnutrition.}

The causes of malnutrition among school children may be divided into social and individual:

I. Social :

a. Living in rooms without windows or sunlight.

b. Lack of bathing facilities.

c. Lack of ventilation.

d. Employment out of school hours.

e. Unsanitary school conditions.

f. Congenital debility.

II. Individual :

a. Food: insufficiency, unsuitability.

b. Injurious sleeping arrangements.

c. Insufficient sleep.

d. Want of cleanliness.

e. Diseases of -

1. Mouth.

2. Teeth.

3. Adenoids.

4. Bronchitis.

5. Tuberculosis.

6. Cardiac diseases.

7. Rheumatism.

8. Post-exanthematous debility.

9. Lack of childhood care, etc. 


\section{The Effect of Malnutrition.}

This condition may be due to any of the causes enumerated above, which in turn may be traced to other causes. These may be economic pressure on the family budget; ignorance of home economics on the part of the housewife; neglect or inability to feed the family properly; congenital or hereditary diseases or defects in the parent or child. Where the normal condition of independence of the family has been disturbed by death, permanent incapacitation or disability of the principal breadwinner, it is very likely that the first item on which economy is practiced is the table, in consequence of which the growing children usually suffer most.

The principal danger of malnutrition is a reduction in the vitality of the child, thus making him more susceptible to disease. Further, the child is a menace to his classmates in that he can more easily become a carrier of infectious disease germs. Pedagogically. it is well known that the educational possibilities of a malnourished child are always at the minimum. He lacks alertness and it is difficult for him to pay attention.

\section{Prevention and Cure of Malnutrition.}

Malnutrition may be prevented by the proper nourishment of the child, both at home and at school, by sufficient periods of rest, pure air, sunlight and frequent bathing. Moreover, the school should supply the lessons which might be taught to the parent as well as to the child on the science of efficient purchase and preparation of foods for family use.

Since there are many children who are ill-nourished, and whose homes are not likely to conduce to an improvement in this direction, it is certainly desirable to inaugurate the service of hot food so that these children may not be deprived of the means wherewith to grow strong because their parents are either incapable of providing the same, or are indifferent and neglectful.

\section{Education and Health.}

From the evidence collected by the Health Department it would appear probable that there are more than 40,000 children in the public schools of New York City who are suffering from malnutrition. While it is true that there are no standards by which a malnourished child may be accurately determined, there is every reason to believe that even this estimate is too low. A special examination made by medical inspectors of the Bureau of Child Hygiene of the Health Department within the past two months in two schools showed that in one building, housing 3,000 children, 650 were malnourished; in the other, with a register of 3,757 children, there were 401 malnourished.

The child who suffers from malnutrition, regardless of what has caused this abnormal state, is very poor clay to mold. Such children are usually torpid, irritable, and, when they are not imper- 
vious to education, are backward and retard the progress of the rest of the class. It can hardly be doubted that the expenditure of money on the education of a child in this condition does not result in much benefit either to the child or the state.

The condition of a child's body is dependent on food, and it is essential to provide him with the most nourishing foods in adequate quantities and at proper times if we wish to fit him to meet the stern realities of life. School feeding, however, should embrace a wider scope than supplying a single meal.

Various experiments tried in England on the effects of the stoppage of school meals have brought about some very interesting results. In Bradford, for instance, during the Whitsuntide holidays, no meals were given. When the children were weighed on their return it was found that they had lost, on an average, one pound, while the control children (those who had not received school meals before the holiday) had gained an average of one-half pound. It took nearly a fortnight to make up for the holidays. Similar results were shown in the effect of the summer holidays. The control children gained on an average thirteen ounces during the four weeks, while the experiment children lost, on an average, one pound.

We have a similar example of this in the Tuberculosis Preventorium for Children, at Farmingdale, N. J. From some unpublished statistics recently compiled by the Superintendent, Miss J. Palmer Quimby, it is learned that children admitted to this institution almost invariably show a decided increase in weight during their ( 4 months) stay. Where children have been discharged at the end of this time, and have subsequently been readmitted, it has often been found that the child's weight had remained stationary, even during a period as long as a year. Almost immediately after readmission a second marked increase in weight began.

Although, of course, a number of factors, such as poverty, and a lack of fresh air, are responsible for this failure to gain in weight at home, the chief reason is to be found in the ignorance of parents in constructing a proper dietary for their children.

\section{School Feeding and Industrial Disturbances.}

The argument has often been advanced that the feeding of children at school causes shiftless parents to shirk their just share of responsibility in the nurture of their offspring. We have not found this so. On the contrary, our employees, coming in contact with the parents in the districts, are often consulted regarding what foods to prepare for children at home and how to prepare them. In New York City the school lunch service is utilized chiefly in the districts where the economic condition of the population is low. This is in accordance also with the English experience. Thus in 1912 the Pontypridd, Merthyr-Tydfil, Ilkeston and Neath districts in England were seriously disturbed by an extensive coal miners' strike. As soon as the community was thrown into idleness the need for school lunches became very pressing, and temporary canteens were opened throughout the districts. 


\section{School Feeding a Palliative Social Measure.}

The need for a school lunch system ought really to be regarded as a symptom of a serious social disorder. The necessity for the feeding of the children at school springs usually from:

1. A demoralized home where the housewife

(a) works out to supplement a meagre wage.

(b) works out because she is the chief bread-winner.

2. Indifference of the housewife.

3. Ignorance of home economics.

The service of a noon meal under the circumstances is at best to be considered inadequate, because-

1. Behind each child in need of such a service is a home which lacks the facilities for proper feeding.

2. For the child in need of the facilities of the lunch service the need is just as great for

(a) breakfast.

(b) supper.

(c) feeding on non-school days.

(d) feeding in the summer recess.

3. If there are children of pre-school age at home no provision is made for them in the present school lunch system.

4. For the mother of such a home nothing is done to make it possible for her to feed children adequately and intelligently.

5. Any desirable effect which flows from the scientific feeding of the child during one meal time at school is very likely to be destroyed by the kind of food the child eats at home during the other meals.

The feeding of children should be made part of a larger social program and ought to be considered as such. Among the matters closely connected, the following deserve consideration:

\section{Material Considerations:}

1. Adequate wages for the chief bread-winner of the family to enable him to permit his wife to stay at home to care for the children.

2. State pensions to widows with children of school age where the mother has no other means of support.

3. Abolition of manufacturing in homes which takes the attention of the mother from home duties,

\section{Educational Considerations:}

Classes to teach mothers and school children the lessons of (a) food selection, (b) food purchase, (c) food hygiene, (d) food preparation, (e) food storage, (f) food usage. 


\section{REPRINT SERIES}

No. 1. Pasteurization of Milk with Suggestions as to Methods and Apparatus to be Employed. By Charles $H$. Kilbourne, Supervising Inspector of Foods in Charge of Pastearizing Plants.

No. 2. The Sanitary Control of Local Milk Supplies through Local Official Agencies, By Ernst J: Lederle, Ph.D., Coumissioner of Healtb.

No. 3. The Rural Origin of Much of the Typhoid Fever of Large Cities, and the Need of-Reorganizing Rural-Public. Health Administra: tion. By. Charles: Frederick-Bolduan; M.D. Assistant to the General, Medical Officer:

No. 4. A Plan for the Reorganization of the Public Health Service of the State of New York. By Charles F. Bolduan, M.D, Assistant to' the General Medical Officer.

No. 5. Hospital Morbidity Statistics. A Simple and Practicable Method of Making Them Uniform and Preparing Them for Analytic Study. By Charles F. Bollduan; M:D.; Assistant to the General Medical Officer.

No. 6. Venereal Diseases. The Attitude of the Department of Health in Relation Thereto By Hermanin M. Biggs, M, G. General Medical Officer.

No. 7. The Municipal Sanatorium at Otisville, By Hermanin M. Biggs, M.D. General Medical Officer.

No. 8. The Tuberculosis, Campaign-Its Influerico on the Methods of Public Health Work Generally. By Hermann M. Biggs, MD: General Officer, and Charlés: F. Bolduan, M.D. Assistant, to the General Medical: Officer.

No. 9. The Contagious Disease Hospitals of New York City. By Robert 7. + J.Wilson, M.D., Superintendent of Hóspitals:

No. 10. The Function of Municipal Authorities in the Control and Improvement of Food Supplies By Ernst J. Lederle; Ph.D. Commissioner of Health:

No. 11. Venereal Diseasest The Relation of the Public Health Authorities - to Their Contral By Charles Frederick Bolduan, M.D. Assistant to the General Medical Officer:

No. 12. Pediculosis Capitis Amang School Children By Jacob Sobel, M.D, Borough Chief; Burcau of Child Hy giene.

No. 13. Prejudices and Superstitions Met with in Medical School Inspec tion, By Jacob Sobel, MD., Borough Chief, Bureau of Child Hygiene.

No. 14. Four Years in the Department of Health. By Ernst. J. Lederle, $\mathrm{PhD}$ : Commissioner of Health.

No, 15. Dirt Sediment Testing $-A$ Factor in Obtaining Clean Mrilk, Wर 1. By.M. C. Schroeder, M, D., Assistant Director, Bureatis of Laboratories.

No. 16. The Administrative Control of Glanders. By E. B. Ackerman, D.V.S., Chlief Veterinarian Buteau of Infectious Diseases.

No. 17. Administrative Control of Whooping Cough By John $\mathrm{S}$ Billings, M.D. Studies in Whooping Cotigh." By William H. Park, M.D, Anna W. Williams, M.D., aud, Others. 


\section{REPRINT SERIES}

\section{(ConTINUED.)}

No. 18. The Next Step in Preventive Medicine. By S. S. Goldwater, M.D., Commissioner of Health.

No. 19. The Use of a Series of Vaccines in the Prophylaxis and Treatment of an Epidemic of Pertussis. By Alfred F. Hess, M.D.

No. 20. After the Sanatorium-What? A Symposium.

No. 21. Further Development of the Usefulness of the Sanatorium. By Charles B. Slade, M.D., Visiting Physician, Otisville Sanatorium:

No. 22. The Health Department's Experience with Typhoid Immunization. By L. I. Harris, M.D., and Morris L. Ogan, M.D.

No. 23. The Viability of the Typhoid Bacillus in Sour Cream: By Charles Krumwiede, Jr., M.D., and W. Carey Noble.

No. 24. The Physical Examination of the Employees of the Department of Health of the City of New York. By Charles B. Slade, M.D.

No. 25. The Neglect to Provide for the Infant in the Antituberculosis Program. By Alfred F. Hess, M.D., Visiting Physician, Willard Parker Hospital.

No. 26. Health Aspects of School Lunches. By Edward F. Brown, New York School Lunch Committee.

No. 27. Causes of the Loss of the Cream Line on Pasteurized Milk By Charles H. Kilbourne.

No. 28. Puerperal Septicaemia. By William H. Guilfoy, M.D., Registrar of Records.

No. 29. Dispensaries: A Growing Factor in Curative and Preventive Medicine. By S. S. Goldwater, M.D., Commissioner of Health.

No. 30. The Rôle of Dairy Inspection in Safeguarding a City's Milk Supply. By Russell Sturgis, Chief, Division of Milk Inspection.

No. 31. Food Regulations of the Department of Health.

No. 32. Complement Fixation in Pertussis. By Miriam Olmstead, M.A., and P. Luttinger, M.D.

No. 33. Venereal Diseases. Their Administrative Control as Developed in the City of New York. By Louis Chargin, M.D., Chief of the Division of Venereal Diseases.

No. 34. The Mosquito as a Pest and as a Carrier of Malaria. By the Bureau of Preventable Diseases and the Sanitary Bureau.

No. 35. Contagious Diseases. Their Administrative Control in Different Cities. By S, Dane Hubbard, M.D., Chief, Division of Contagious Diseases.

No. 36. A Bacteriological Study of an Epidemic of Septic Sore Throat. By Charles Krumwiede; Jr., and Eugenia Valentine (from Bureau of Laboratories).

The department will enter into exchange of publications with public health, medical and scientific organizations, societies, laboratories, journals and authors. Applications for publications should be addressed to the Director, Bureau of Public Health "Education, Department of Health, corner Centre and Walker Streets, New York City. 